\title{
Imerslund-Grasbeck Syndrome: A Case Report
}

\author{
Ghosh TN ${ }^{1}$, Nayek $K^{2}$, Banerjee $A^{3}$ \\ ${ }^{1}$ Dr. Taraknath Ghosh, MBBS. MD. (Paediatrics), Associate Professor, ${ }^{2}$ Dr. Kaustav Nayek, MBBS. DCH, MD \\ (Paediatrics), Associate Professor. ${ }^{3} \mathrm{Dr}$. Arundhati Banerjee, MD (Pediatrics) Post Graduate Trainee. All from the \\ Department of Paediatrics, Medical College, Burdwan, India
}

Address for correspondence Dr. TN Ghosh, E-mail: tnghosh39@gmail.com

\begin{abstract}
Imerslund- Grasbeck syndrome is a rare autosomal recessive disorder due to selective malabsorption of Vitamin B12 at the level of cobalamin-intrinsic factor receptor mutation in the terminal ileum resulting in megaloblastic anaemia with proteinuria. Early detection of this rare disorder would enable screening and genetic counselling for asymptomatic family members.
\end{abstract}

Key words: Imurslund Grasbeck Syndrome, Megaloblastic anaemia, Proteinuria

\section{Introduction}

Familial selective malabsorption of Vitamin B12 associated with proteinuria was first described by Imerslund Grasbeck et al in 19601,2. Inherited as an autosomal recessive trait, Imerslund-Grasbeck syndrome is characterized by the onset of megaloblastic anemia and asymptomatic proteinuria during the first 2 years of life $^{3}$. About 300 cases have been published worldwide, with most being reported from the Mediterranean region.

\section{The Case}

We present a six and a half years old female child with chief complaints of irritability, lack of appetite, gradually progressive pallor, exercise intolerance and hyperpigmentation of knuckles for the past two years. There was no history of abnormal eating habits bone pain, bleeding from other sites, fever, altered sensorium or blood transfusion in the past. She had been treated with iron supplements for variable length of time. She was born of non-consanguineous marriage. Her birth, development, past and family history were uneventful. Her general examination showed moderate pallor, edema and significant hyperpigmentation of her knuckles of both her hands and feet. Abdominal examination revealed no organomegaly. Other systemic examinations were normal.

Her peripheral blood smear revealed a microcytic, hypochromic anaemia with normal ferritin levels. Hemoglobin electrophoresis was normal pattern. Stool for occult blood examination was negative. Her bone marrow examination showed: Cellular smear, megaloblastic erythroid hyperplasia with giant megakaryocytes. Serum B12 level was 160pg/ml; however serum folate level was $10 \mathrm{ng} / \mathrm{ml}$. Besides, urine examination showed Albuminuria ranging from1+ to 2+ and a 24 hour quantitative estimation of albumin being 125.58 grams.

Following this suggestive report the patient was treated with a course of oral antibiotics to exclude bacterial overgrowth syndrome and she was started on oral vitamin supplements to exclude other deficiencies. However vitamin B12 further declined to128 pg/ $\mathrm{ml}$. Thereafter, the patient was started on parenteral vitamin B12 injections daily for the first 10 days followed by monthly injections. With treatment she is being followed up in the OPD with marked improvement of pallor, knuckle hyperpigmentation with a gradual rise of hemoglobin levels. 


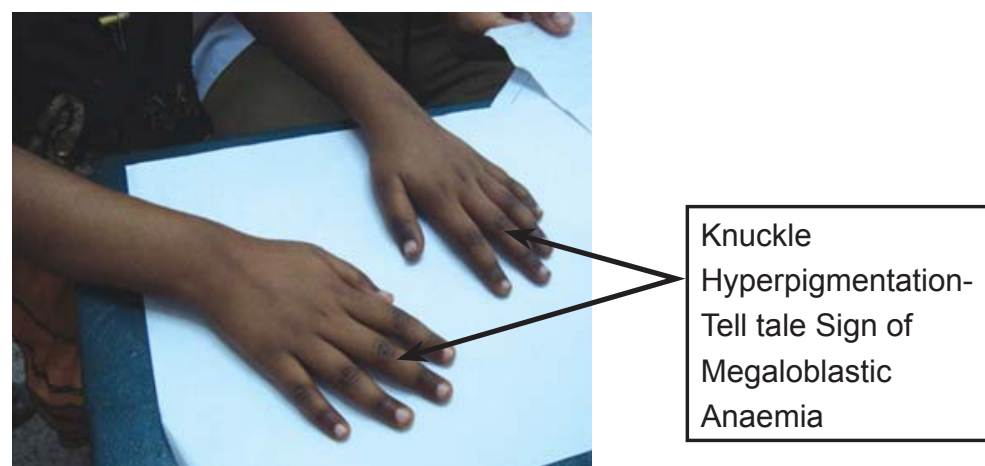

Fig 1: Imurslund Grasbeck Syndrome

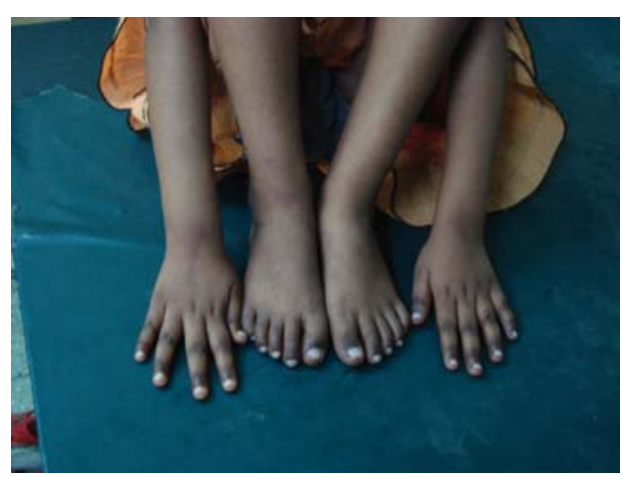

Fig 2: Knuckle hyperpigmentation-Tell tale sign of megaloblastic anaemia

\section{Discussion}

Imerslund syndrome should be considered when the three typical features are present: macrocytic anemia, decreased serum B12 level and proteinuria 4 . The proteinuria is neither typically glomerular nor tubular in nature ${ }^{5}$.

Imurslund Grasbeck syndrome is caused by a selective incapacity of vitamin B12 absorption in the intestine. CUBN and $A M N$ encode the two subunits (cubilin and amnion less) of the cobalamin-intrinsic factor receptor of the ileal mucosa ${ }^{6}$. The cubilinamnionless complex is called cubam and is considered to be essential for intestinal cobalamin uptake, renal protein reabsorption and early rodent embryogenesis.

In our case, the serum folate level was normal. This was further supported by the fact that initially on administration of low dose oral folate supplements, her symptoms improved but her vitamin B12 levels dropped to $128 \mathrm{pg} / \mathrm{ml}$. Barium studies were done to exclude other causes of malabsorption, which proved to be normal. She was treated with a course of antibiotics that would eliminate the chances of deficiency states due to bacterial overgrowth. Radiocobalamin absorption studies to exclude pernicious anemia was found to be negative, however, transcobalamin levels could not be done due to constraints of availability and economy in our set up.

Despite these constraints, the symptoms of megaloblastic anemia, reduced vitamin B12 levels and persistent proteinuria together with a dramatic response to parenteral therapy strongly suggests this rare diagnosis.

\section{Conclusion}

To conclude, Imerslund Grasbeck Syndrome, a rare diagnosis should always be suspected in a child with pallor, reduced vitamin B12 levels and persistent proteinuria in the absence of any renal impairment. This rare disorder has a simple and effective treatment to avoid the devastating neurological sequelae.

\section{References}

1. Imerslund 0. Idiopathic chronic megaloblastic anaemia in children. Acta Pediatr Suppl 1960; (Suppl 119):1-115.

2. Grasbeck R, Gordin R, Kantero I, Kuhlback B. Selective vitamin B12 malabsorption and proteinuria in young people. A syndrome. Acta Med Scand 1960;167:289-96.

3. Bonfin C, Strapasson E, Delle LA, Malvezzi M, Moreira VA, Netto AG, Martins FL, Bitencourt MA, Pasquini R. [Imerslund-Grasbeck syndrome: report of two cases] J Pediatr (Rio J) 1999;75:477-80.

4. Flechelles O, Schneider P, Lesesve JF, Baruchel A, Vannier JP, Tron P, Schaison G. [Imerslund's disease. Clinical and biological aspects. Apropos of 6 cases] Arch Pediatr 1998;5:344-5.

5. Wahlstedt Froberg V, Petterson T, Aminoff M, Dugu B, Grasbeck R: Proteinuria in Cubilin Deficient Patient with selective Vit B12 malabsorption. Pediatr Nephrol 2003;18:417-21.

6. Tanner SM, Aminoff M, Wright FA, Liyanarachchi S, Kuronen M, Saarinen A, Massika O, Mandel H, Broch $\mathrm{H}$, de la Chapelle A: Amnionless, essential for mouse gastrulation, is mutated in recessive hereditary megaloblastic anemia. Nat Genet 2003;33:426-29.

\section{How to cite this article?}

Ghosh TN, Nayek K, Banerjee A. Imerslund-Grasbeck Syndrome: A Case Report. J Nepal Paediatr Soc 2011;31(3):249-250. 